\title{
30. MOLECULAR INDICATORS OF THE SUPPLY OF MARINE AND TERRIGENOUS ORGANIC MATTER TO A PLEISTOCENE ORGANIC-MATTER-RICH LAYER IN THE ALBORAN BASIN (WESTERN MEDITERRANEAN SEA) ${ }^{1}$
}

\author{
Marc Hauschildt, ${ }^{2}$ Joachim Rinna, ${ }^{2}$ and Jürgen Rullkötter ${ }^{2,3}$
}

\begin{abstract}
The organic matter in sediment series across two organic-matter-rich layers from Ocean Drilling Program Hole 977A drilled in the Alboran Basin of the Western Mediterranean Sea has been characterized by organic geochemical methods. Organic carbon contents reached more than $2 \%$ in the organic-matter-rich layer and was $\sim 1 \%$ in the background sediment under and overlying it. Molecular compositions of the extractable bitumens in the organic-matter-rich layer for a wide range of compound groups are broadly similar to those of the background sediments. The organic matter in the organic-matter-rich layer is enriched in marine biomarkers, especially long-chain diols and keto-ols and particularly sterols. A higher supply of landderived material to the sediment during formation of the organic-matter-rich layer is indicated by concentrations of long-chain alkanes and $n$-alcohols largely following the organic carbon profile. The elevated terrigenous runoff during times of more humid land climate may have fertilized marine bioproductivity.
\end{abstract}

\section{INTRODUCTION}

The Alboran Sea is the key area to understand the Atlantic Ocean influence on the post-Messinian paleoceanography of the Mediterranean Sea. One of the more important results of Ocean Drilling Program (ODP) Leg 161 was the discovery of sapropel-like organicmatter-rich layers in this westernmost part of the Mediterranean Sea. Sapropels-dark-green to black, organic-matter-rich layers with total organic carbon (TOC) content $>2 \%$ according to the definition of Kidd et al. (1978) —were known before to occur only in the eastern part of the Mediterranean Sea (e.g., Ryan, Hsü, et al., 1973; Hsü, Montadert et al., 1978) and in the Tyrrhenian Sea (Kastens, Mascle, et al., 1990).

The Alboran Sea between Spain and Morocco is $\sim 400 \mathrm{~km}$ long, $200 \mathrm{~km}$ wide, and $2000 \mathrm{~m}$ deep. It is bounded by the southern Balearic Basin in the east and the Gibraltar Strait in the west. Through the Gibraltar Strait it is connected with the Atlantic Ocean surface water. It shows a complex morphology with many sub-basins, ridges, and seamounts. A local elevation shapes the tiny Spanish Alboran Island (Fig. 1).

The Atlantic water flowing into the Mediterranean Sea through the Gibraltar Strait develops two extensive anticyclonic gyres, one in the western part and the other in the eastern part of the Alboran Basin (Tintoré et al., 1988; Fig. 2). Whereas the western gyre can be explained by the topographical setting and the Coriolis force (EUROMODEL Group, 1975), the eastern gyre remains unexplainable.

On the southwest Spanish coast an upwelling system (Minas et al., 1984; Vergnaud-Grazzini and Pierre, 1991) is supplied with nutrients from both the outflowing Levantine Intermediate Water and Mediterranean Deep Water (Kinder and Parrilla, 1987) and from the inflowing Atlantic water (Minas et al., 1984). The primary production here has been estimated at $>200 \mathrm{~g} \mathrm{C} \mathrm{m/yr} \mathrm{(Minas} \mathrm{et} \mathrm{al.,} \mathrm{in} \mathrm{pers.}$ comm. to Vergnaud-Grazzini and Pierre, 1991). Because of a persistent density front (Almeria-Oran Front) along the eastern basin demarcation, the Atlantic water is accelerated in a southerly direction

'Zahn, R., Comas, M.C., and Klaus, A. (Eds.), 1999. Proc. ODP, Sci. Results, 161: College Station, TX (Ocean Drilling Program)

Institut für Chemie und Biologie des Meeres (ICBM), Carl von Ossietzky Universität Oldenburg, Postfach 2503, D-26111 Oldenburg, Federal Republic of Germany.

${ }^{3}$ Corresponding author: J.Rullkoetter@ogc.icbm.uni-oldenburg.de toward the Algerian coast and develops into a strong jet strictly toward the east (Tintoré et al., 1995). Along this narrow stream, nutrient-rich deep waters are locally upwelled and induce regional fertilization in the surface water (Prieur et al., 1993).

These signatures may be recorded in the underlying sediments, but may probably have varied during glacial/interglacial cycles. Abrantes (1988) deduced glacial/interglacial variations of productivity from paleoceanographic studies. Compared to the recent conditions, quite different atmospheric and wind systems prevailed during the last interglacial maximum (COHMAP Members, 1988). This different wind pattern may have led to an eastward shift of the gyres and to a modification of the upwelling system (Vergnaud-Grazzini and Pierre, 1991). The $\Delta \delta^{13} \mathrm{C}$ data suggest a nutrient depletion of Atlantic water during the last interglacial maximum (Zahn et al., 1987), which may have reduced the fertility of the Western Mediterranean Sea (Vergnaud-Grazzini and Pierre, 1991).

Terrigenous material is supplied to the Alboran Basin directly from the numerous rivers, essentially the Andarax, Rio Guadalfio, Rio Guadalhorce, and Muluja effluents (Fig. 2). Indirectly, terrigenous matter is transported from the Guadalquivir River over the Gulf of Cadiz with the Atlantic inflow (Grousset et al., 1988). Local winds transport terrigenous material into the Alboran Basin too, especially during the winter, by a strongly developed depression over the whole Mediterranean Sea. Sahara dust has been shown to be present in Holocene sediments of the Adriatic Sea (Tomadin et al., 1984).

This study attempts to provide information on variation in the supply of terrigenous and marine organic matter to the sediments of the Alboran Basin during the short time interval represented by a Pleistocene organic-matter-rich layer recovered at $\sim 77 \mathrm{~m}$ depth in Hole 977A of Leg 161. For this purpose, nonpolar and polar lipids were extracted from the sediments and analyzed on a molecular level. A second interval covering an organic-matter-rich layer at about 164 mbsf from the same hole was only analyzed for total organic and carbonate carbon contents.

\section{ANALYTICAL METHODS}

We investigated a total of 18 core samples from Hole 977A (Table 1). After freeze-drying and grinding, the sediments were analyzed for total carbon (TC) content coulometrically in a Ströhlein Coulomat 


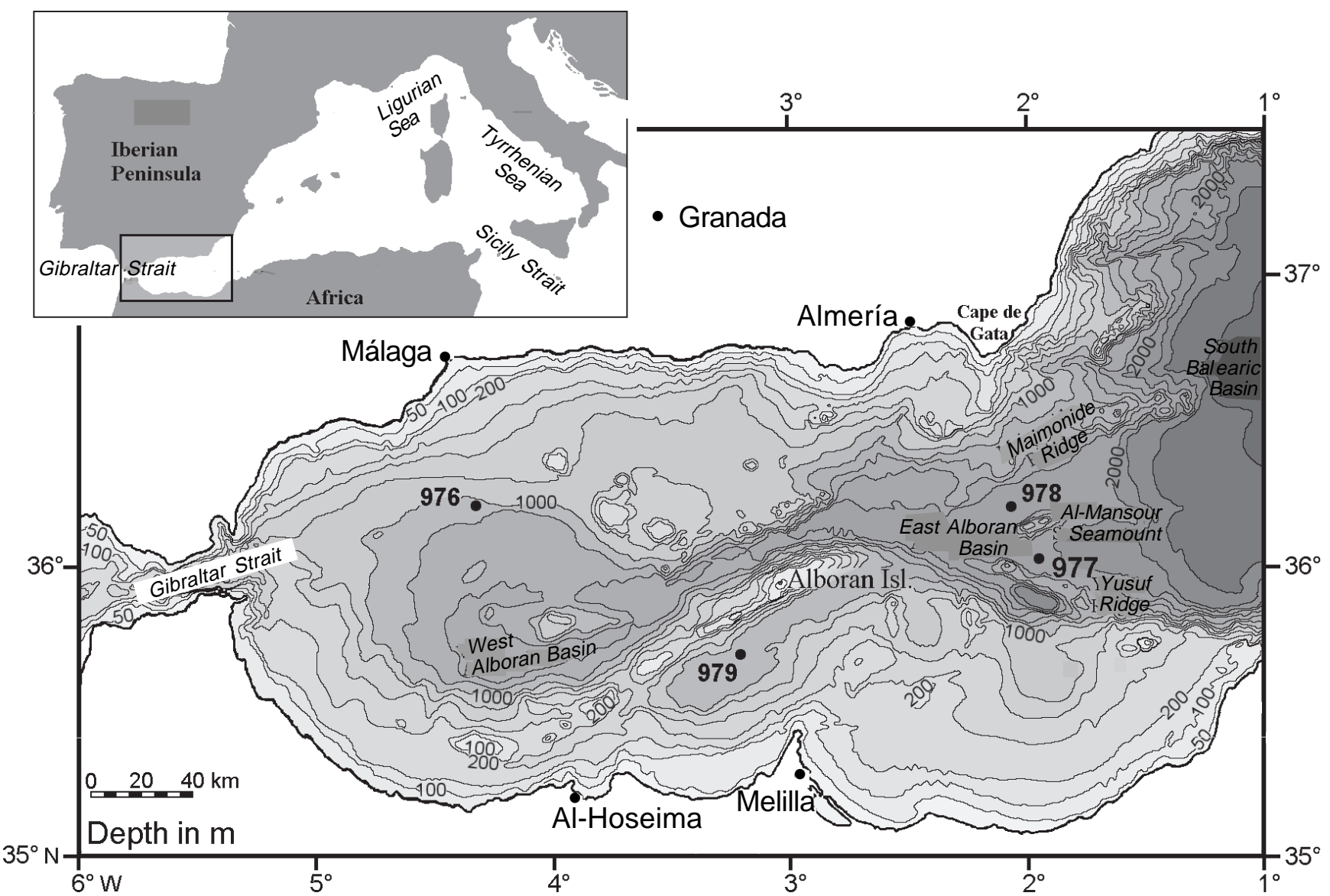

Figure 1. Bathymetric map of the Alboran Basin and location of Site 977 and other sites of Leg 161.

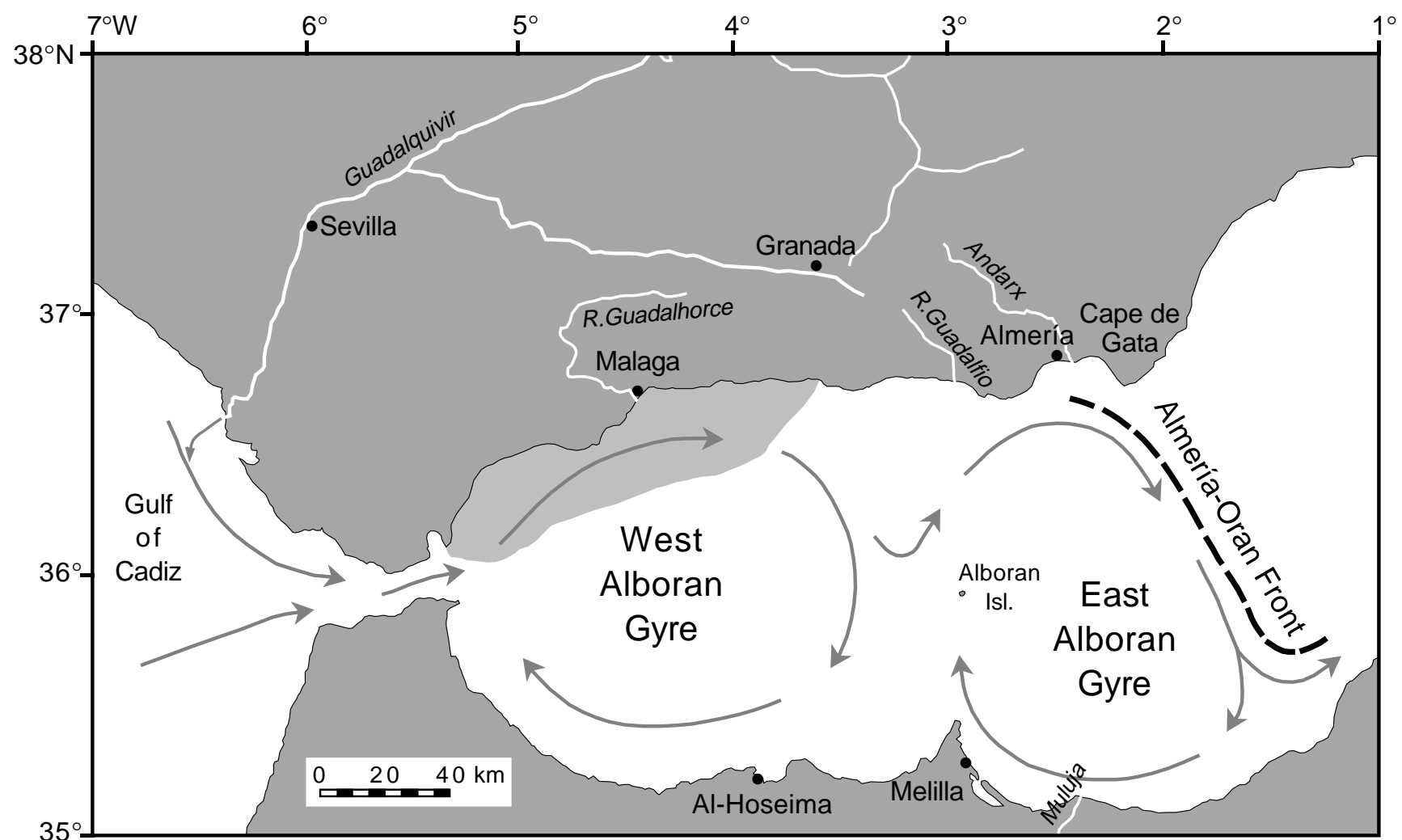

Figure 2. Anticyclonic gyres of the Alboran Sea (schematically after Arnone et al., 1990) and upwelling system on the South Spanish Coast (shaded; after Minas et al., 1984). 
Table 1. Sample identification, depth below seafloor (mbsf), total carbon (TC), total inorganic carbon (TAC), calcium carbonate $\left(\% \mathrm{CaCO}_{3}\right.$, calculated), and organic carbon (TOC) contents.

\begin{tabular}{lccccc}
\hline $\begin{array}{c}\text { Core, section, interval } \\
(\mathrm{cm})\end{array}$ & $\begin{array}{c}\text { Depth } \\
(\mathrm{mbsf})\end{array}$ & $\begin{array}{c}\mathrm{TC} \\
(\%)\end{array}$ & $\begin{array}{c}\mathrm{TAC} \\
(\%)\end{array}$ & $\begin{array}{c}\mathrm{CaCO}_{3} \\
(\%)\end{array}$ & $\begin{array}{c}\mathrm{TOC} \\
(\%)\end{array}$ \\
\hline 161-977A- & & & & & \\
9H-05, 53-55 & 77.04 & 5.13 & 4.23 & 35.3 & 0.90 \\
9H-05, 63-65* & 77.14 & 5.89 & 5.01 & 41.7 & 0.88 \\
9H-05, 73-75* & 77.24 & 6.98 & 5.03 & 41.9 & 1.94 \\
9H-05, 80-82* & 77.31 & 7.04 & 4.77 & 39.7 & 2.27 \\
9H-05, 86-88* & 77.37 & 6.32 & 4.38 & 36.5 & 1.94 \\
9H-05,92-94* & 77.43 & 5.86 & 4.41 & 36.7 & 1.45 \\
9H-05,98-100 & 77.49 & 5.65 & 4.54 & 37.8 & 1.11 \\
9H-05, 103-105* & 77.54 & 6.32 & 5.42 & 45.2 & 0.50 \\
9H-05, 113-115 & 77.64 & 4.84 & 3.87 & 32.2 & 0.97 \\
9H-05, 124-126 & 77.75 & 5.03 & 4.01 & 33.4 & 1.02 \\
18X-05, 118-120 & 163.19 & 3.93 & 3.12 & 26.0 & 0.80 \\
18X-05, 140-142 & 163.41 & 3.40 & 2.76 & 23.0 & 0.64 \\
18X-05, 148-150 & 163.49 & 3.52 & 2.84 & 23.6 & 0.68 \\
18X-06, 15-17 & 163.66 & 7.09 & 5.78 & 48.2 & 1.31 \\
18X-06, 18-20 & 163.69 & 5.69 & 3.80 & 31.6 & 1.90 \\
18X-06, 23-25 & 163.74 & 5.22 & 3.78 & 31.5 & 1.44 \\
18X-06, 33-35 & 163.84 & 5.41 & 4.20 & 35.0 & 1.20 \\
18X-06, 43-45 & 163.94 & 5.43 & 4.69 & 39.0 & 0.74 \\
\hline
\end{tabular}

Note: $*=$ selected for molecular analyses.

702. Carbonate contents were determined after acidification as carbon dioxide using a UIC-Coulometrics CM 5012 device. Total organic carbon (TOC) content was calculated as the difference between total and inorganic carbon contents.

Dry sediment $(4 \mathrm{~g})$ was extracted with a dichloromethane/1\% methanol (v/v) mixture four times (once at $50 \mathrm{~mL}$ followed by three times at $30 \mathrm{~mL}$ ) in an ultrasonic bath. The combined decanted extracts were concentrated by rotary evaporation to $2 \mathrm{~mL}$ and dried in a stream of nitrogen at mild temperature $\left(30^{\circ}-35^{\circ} \mathrm{C}\right)$. Extract yields were determined gravimetrically. Elemental sulfur was removed from the total extracts with activated copper filings.

Separation of the extracts into fractions of different polarities was carried out after addition of internal standards (squalane, anthracene$\mathrm{d}_{10}, 5 \alpha$-androstan-17-one, $5 \alpha$ androstan-3ß-ol and erucic acid $\left[n-\mathrm{C}_{22: 1}\right.$ fatty acid]). Before column chromatographic separation, the asphaltenes were precipitated by adding an excess of $n$-hexane. The $n$-hexane-soluble portion was separated by medium-pressure liquid chromatography (MPLC; Radke et al., 1980) into fractions of nonaromatic hydrocarbons, aromatic hydrocarbons, and heterocompounds (NSO fraction).

Subsequently, ketones, esters, and $n$-alkanols $\left(>\mathrm{C}_{20}\right)$ were separated from the more polar NSO fraction by flash chromatography (Still et al., 1978). For this purpose, a $10-\times 200-\mathrm{mm}$ column was filled with $5 \mathrm{~g}$ of silica gel $60(40-63 \mu \mathrm{m}$, deactivated with $5 \%$ by weight of water) and washed with $50 \mathrm{~mL}$ dichloromethane. The less polar fraction was eluted with $60 \mathrm{~mL}$ dichloromethane under a moderate overpressure of nitrogen. The other compounds were removed from the column with $100 \mathrm{~mL}$ of a mixture of dichloromethane and $10 \%$ by volume of methanol. The polar portion of the NSO fraction was separated into an acid fraction and a steroid alcohol fraction using a column filled with $\mathrm{KOH}$-impregnated silica gel (McCarthy and Duthie, 1962; modified after Hinrichs et al., 1995). All fractions were concentrated as described for the whole extracts and weighed. For analysis of the molecular constituents, the hetero compound fractions were silylated with $\mathrm{N}$-methyl-N-trimethylsilyl-trifluoroacetamide (MSTFA).

Gas chromatography was conducted on a Hewlett-Packard 5890 Series II instrument equipped with a temperature-programmed coldinjection system (Gerstel KAS 3 ) and a fused silica capillary column (J\&W DB-5; length $=30 \mathrm{~m}$, inner diameter $=0.25 \mathrm{~mm}$, film thickness $=0.25 \mu \mathrm{m})$. Helium was used as the carrier gas, and the temperature of the oven was programmed from $60^{\circ} \mathrm{C}\left(1 \mathrm{~min}\right.$ isothermal) to $305^{\circ} \mathrm{C}$ (50 min isothermal) at a rate of $3^{\circ} \mathrm{C} / \mathrm{min}$.

GC/MS studies were performed with the same type of gas chromatograph (helium as carrier gas) and a temperature program from $60^{\circ} \mathrm{C}$ (1 min isothermal) to $300^{\circ} \mathrm{C}(50 \mathrm{~min}$ isothermal) at a rate of $3^{\circ} \mathrm{C} / \mathrm{min}$. The gas chromatograph was coupled to a Finnigan SSQ $710 \mathrm{~B}$ mass spectrometer operated at $70 \mathrm{eV}$. Structural assignments of individual compounds are based on comparison of relative gas chromatographic retention times and mass spectra with those reported in the literature. Quantification was performed relative to the amount of internal standards with mass correction for trimethylsilylated compounds.

All ten samples from Section 161-977A-9H-5 were analyzed for lignin phenols by high-performance liquid chromatography (HPLC). The lignin phenols were released from the macromolecular organic matter as copper oxide $(\mathrm{CuO})$ oxidation products following the method of Hedges and Parker (1976), modified by Eggers (1994) and refined by J. Lobbes (pers. comm., 1996). Dry sediment (0.5-1.0 g), mixed with $\mathrm{CuO}(0.5 \mathrm{~g})$ and ammoniumferro(II)-sulfate hexahydrate, was heated in teflon bombs $\left(3 \mathrm{hr}, 150^{\circ} \mathrm{C}\right)$ after the addition of $5 \mathrm{~mL}$ $2 \mathrm{~N}$ sodium hydroxide solution. The suspensions were acidified with hydrochloric acid $(30 \%)$ and extracted with diethylether $(5 \mathrm{~mL})$. These extracts were directly analyzed on a DAD L-4500 HPLC instrument (Merck/Hitachi).

\section{RESULTS AND DISCUSSION}

The results of elemental analysis for total organic carbon (TOC) and carbonate content in the two investigated sequences across organic-matter-rich layers in the Alboran Basin Hole 161-977A are compiled in Table 1 and Figure 3. The organic carbon contents in Sections 161-977A-18X-5 and -6 vary between $0.74 \%$ and $1.90 \%$ while in Section 977A-9H-5 they range from $0.88 \%$ to $2.27 \%$. The more pronounced symmetric form of the TOC profile in the samples from Section 977A-9H-5 and the more regular sample spacing led us to investigate this sequence in greater detail on a molecular level. TOC content of organic-matter-rich layers in the Western Mediterranean Sea are distinctly lower than those in eastern Mediterranean sapropels, which, considering the proximity to the African and Spanish coasts, may mainly reflect a higher supply of clastic material from the continent and thus a higher degree of terrigenous dilution, but may also be a factor of lower primary productivity and inferior conditions for organic matter preservation in the Alboran Basin. In the background sediments below and above the organic-matter-rich layers, recovered in the Alboran Sea during Leg 161, the average TOC content is more than twice as high as the deep-ocean sediment average of $0.3 \%$ reported by McIver (1975) and distinctly higher than in nonsapropel background sediment of the Eastern Mediterranean Sea (Emeis, Robertson, Richter, et al., 1996). Maximum TOC values at the four sites occupied during Leg 161 in the Alboran Sea are in the range of $1.27 \%$ (Site 978) to $2.50 \%$ (Site 977; Comas, Zahn, Klaus, et al., 1996). The carbonate contents of the investigated samples are between $20 \%-50 \%$ and indicate varying influences of bioproductivity, dilution by noncarbonate material and post-depositional carbonate solution; the carbonate data are positively correlated with the TOC values.

\section{Molecular Composition}

Six of the ten samples from Section 161-977A-9H-5 (marked in Fig. 3) were selected for further molecular organic geochemical investigations. The sterols are quantitatively the most important group of compounds among those separated by liquid chromatography and analyzed quantitatively, while the $n$-aldehydes represent the least abundant group (Fig. 4). The data in Figure 4 represent the sum of concentrations of identifiable single compounds (together making up $4 \%$ to $9 \%$ of the total extracts), but are not identical to the amounts of total liquid chromatography fractions separated from the total extracts. Among the different compound groups, only the $n$-alkanes correlate positively with the TOC values of the entire interval studied. The long-chain $n$-alkenones, $n$-alkanols, fatty acids, and 
977A

$-9 H-5,53-126 \mathrm{~cm}$

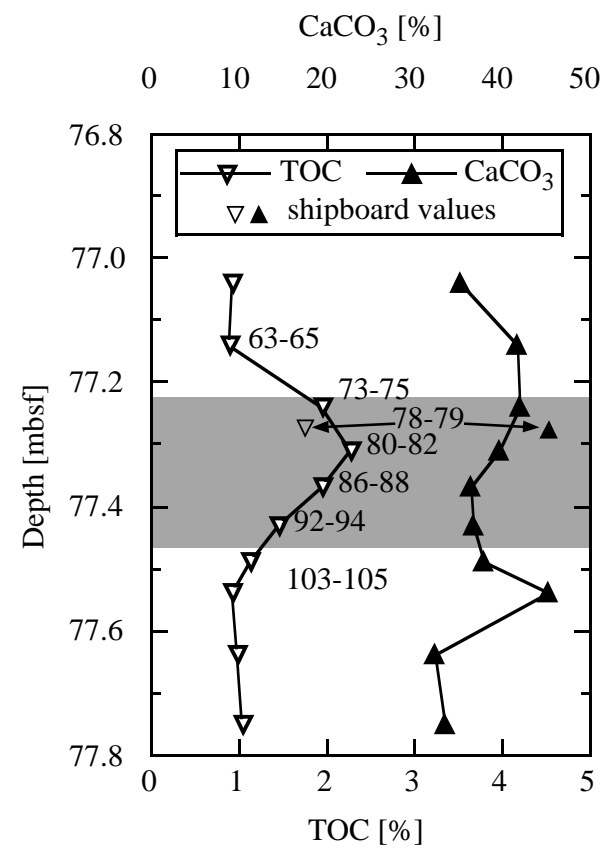

977A

$-18 X-5,118 \mathrm{~cm}$ through

$18 X-6,45 \mathrm{~cm}$

$$
0
$$

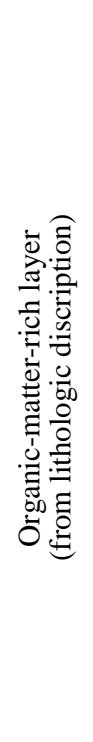

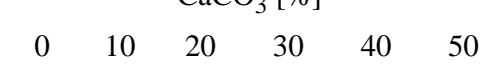

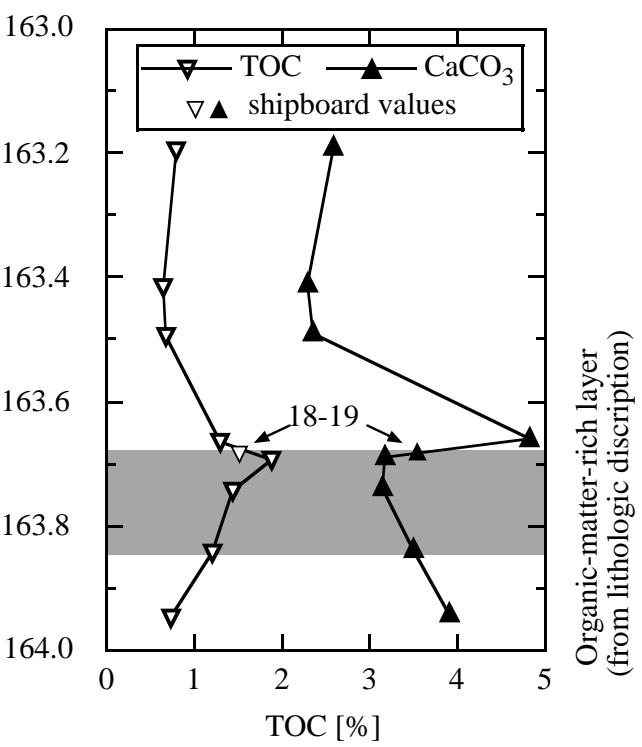

Figure 3. Total organic carbon (TOC) and carbonate contents (as $\mathrm{CaCO}_{3}$ ) in sediments across two sapropel layers (Samples 161-977A-9H-5, 53-126 cm, 18X$5,118-150 \mathrm{~cm}$, and $18 \mathrm{X}-6,0-45 \mathrm{~cm})$.

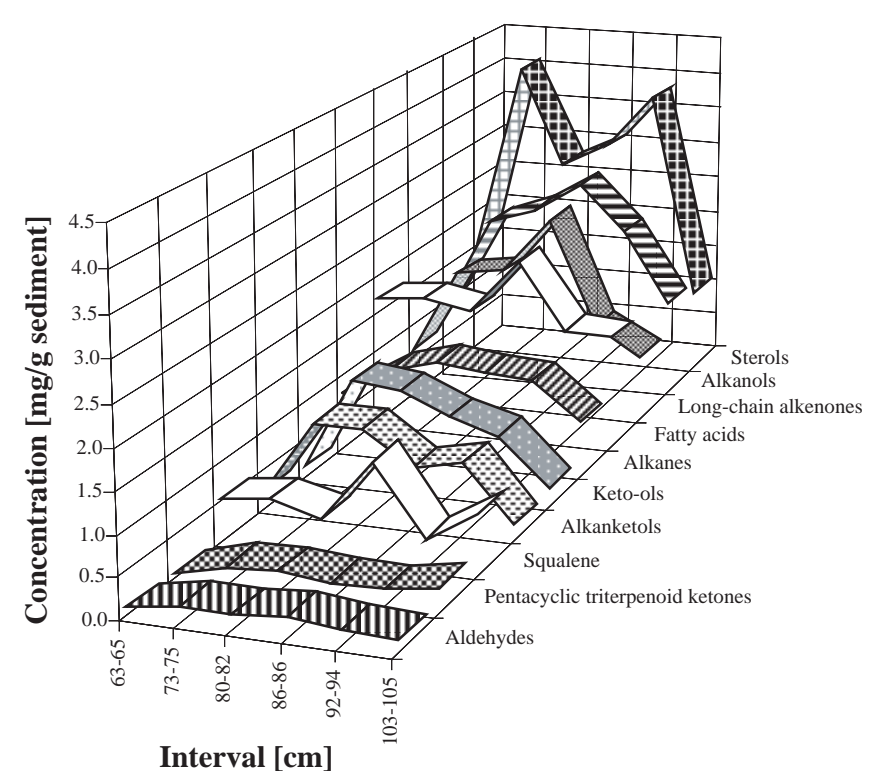

Figure 4. Absolute amounts (mg/g sediment) of different organic compound classes, obtained by liquid chromatography of total extracts, in selected sediments from Section 161-977A-9H-5.

squalene have a significant maximum in the 86 - to 88 -cm interval of Section 161-977A-9H-5, while the $n$-alkanolones and diols have a minimum there. The ketols and diols show a distinct positive correlation with each other $(\mathrm{R}=0.97)$.

\section{n-Alkanes}

The $n$-alkanes in the nonaromatic hydrocarbon fraction of the extracts cover a range of chain lengths between $\mathrm{C}_{17}$ and $\mathrm{C}_{40}$ (Fig. 5). The
$\mathrm{C}_{23}$ and $\mathrm{C}_{35} n$-alkanes dominate and exhibit a pronounced odd-overeven carbon-number preference typical of an origin of terrestrial higher plants (Eglinton et al., 1962). The $n$-alkanes between $\mathrm{C}_{15}$ and $\mathrm{C}_{23}$ have a low abundance and do not exhibit a characteristic pattern of an intense autochthonous supply of phytoplanktonic organic matter (Blumer et al., 1971). The distribution without any preference may be due to co-occurring phyto- and zooplankton signals, with the even-over-odd carbon-number preference of the latter (Giger and Schaffner, 1977) being superimposed on the odd-over-even carbonnumber predominance of the phytoplankton (Blumer et al., 1971), but the broad and smooth distribution of short-chain $n$-alkanes may also be a result of the presence of a certain amount of recycled, more mature organic matter commonly found in deep-sea sediments (e.g., Tissot et al., 1980; Summerhayes, 1981). The $n$-alkanes with chain lengths beyond $\mathrm{C}_{36}$ may be a result of the incorporation of coccolithophore biomass into the sediments (Volkman et al., 1980c), which is likely to be also responsible for the presence of the long-chain $n$-alkenones (Volkman et al., 1980b).

Another aspect of the $n$-alkane distributions is the unexpectedly small variation of their distribution pattern over the organic-matterrich layer. Together with the fact that organic-carbon-normalized concentrations of $n$-alkanes vary little, that is, they increase with the increase of total organic carbon, this shows that deposition of the organic-matter-rich layer is accompanied by an increase in the supply of terrigenous organic matter to the Alboran Basin.

\section{Fatty Acids}

While the $n$-alkanes show mainly a terrestrial influence, the fatty acids are dominated by short-chain marine or microbial components. The chain length of the fatty acids ranges from $\mathrm{C}_{11}$ to $\mathrm{C}_{30}$ with a distinct maximum at $\mathrm{C}_{16}$ and a strong even-over-odd carbon number predominance (Fig. 6). Diatoms may be the main contributors of the fatty acids in the Alboran basin sediments because they mainly produce $\mathrm{C}_{16}$ and $\mathrm{C}_{18}$ homologs (Volkman et al., 1980a). Dinoflagellates mainly biosynthesize $\mathrm{C}_{18}, \mathrm{C}_{20}$, and $\mathrm{C}_{22}$ fatty acids (Harrington et al., 1970), 
while coccolithophores have $\mathrm{C}_{14}$ and $\mathrm{C}_{16}$ (Volkman et al., 1981), green algae $C_{16}$ and $C_{18}$ (Patterson, 1970), blue-green algae $C_{14}, C_{16}$, and $\mathrm{C}_{18}$ acids (Kenyon et al., 1972).

\section{n-Alkanols}

The $n$-alkanols exhibit a mainly terrestrial carbon number distribution pattern (Fig. 7). The chain lengths range from $\mathrm{C}_{12}$ to $\mathrm{C}_{32}$ with a predominance of the higher-carbon-number homologs and a strong even-over-odd carbon-number preference. Noteworthy is the depth profile of the $\mathrm{C}_{22} n$-alkanol. Algal mats have been reported to contain this compound as a major constituent (Cardoso et al., 1976), but the strong correlation with the long-chain fatty acids in the studied interval from the Alboran Basin ( $\mathrm{R}=0.95$; Fig. 8) favors a common ter-
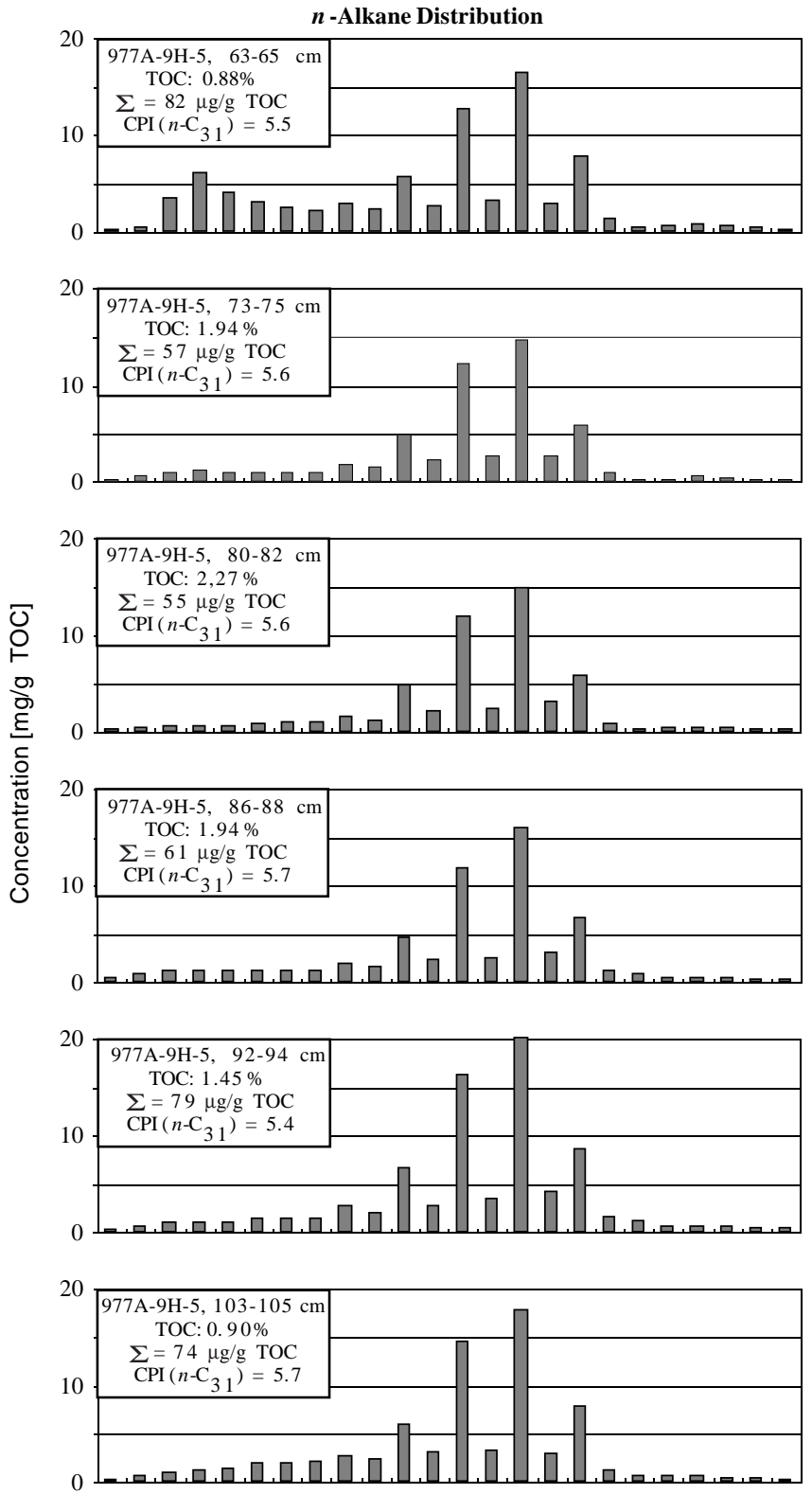

171819202122232425262728293031323334353637383940

\section{Carbon number}

Figure 5. Distribution of $n$-alkanes in selected sediments from Section 161977A-9H-5. restrial source of both the $\mathrm{C}_{22}$ alcohol and the long-chain fatty acids, possibly initially ester-linked.

\section{Ketols and Diols, Long-Chain Alkenones}

The sum of the concentrations of 1-hydroxytriacontan-15-one and 1-hydroxydotriacontan-15-one and the sum of the concentrations of all long-chain diols (Table 2) correlate strongly with each other over depth, while both classes apparently do not have any relationship with the long-chain alkenones (Fig. 9). This lack of correlation of the long-chain alkenones with the other two compound classes corroborates earlier reports of different sources. Prymnesiophytes, and particularly coccolithophores, are well known as producers of heptatriaconta-8(E),15(E),22(E)-triene and heptatriaconta-15(E),22(E)-diene
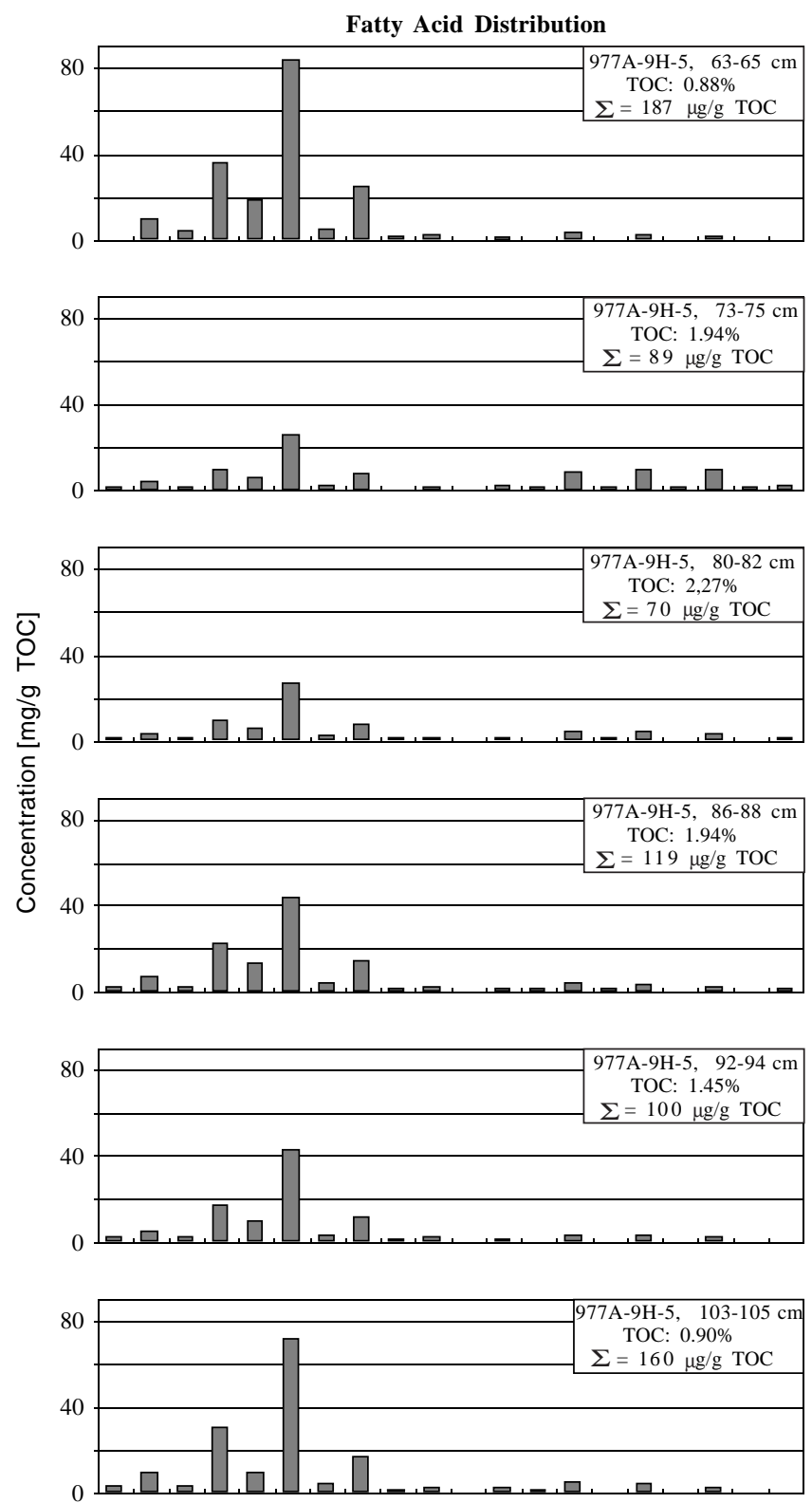

1112131415161718192021222324252627282930

Carbon number

Figure 6. Distribution of fatty acids in selected sediments from Section 161977A-9H-5. 

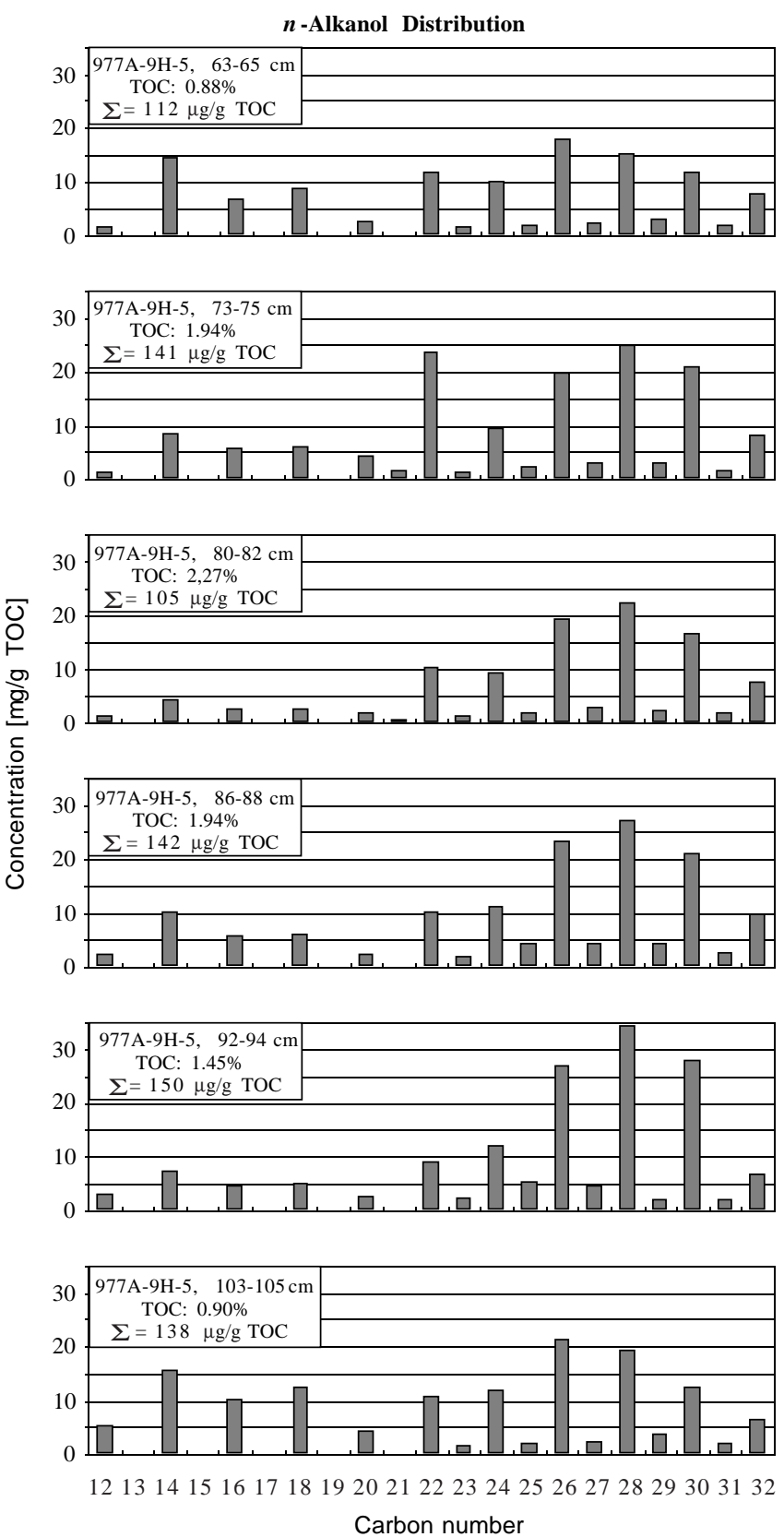

Figure 7. Distribution of $n$-alkanols in selected sediments from Section 161977A-9H-5.

as well as other long-chain alkenones and alkenoates (Prahl and Wakeham, 1987). The source of the ketols and diols has been discussed controversially for a long time. While Morris and Brassell (1988) suggested cyanobacteria as a probable source, Volkman et al. (1992) identified specific marine green algae (Eustigmatophytes) as a more likely source of these compounds. The suggestion of de Leeuw et al. (1981) that coccolithophores may be the source of ketols and diols as of the $n$-alkenones could not be confirmed here.

Paleo-sea-surface temperatures based on the ratio of di- and triunsaturated long-chain ketones (Prahl and Wakeham, 1987) show a distinct increase from $19^{\circ} \mathrm{C}$ to $22^{\circ} \mathrm{C}$ over the short sediment interval studied here, with the main increase occurring after the deposition of the organic-matter-rich layer (Fig. 10).

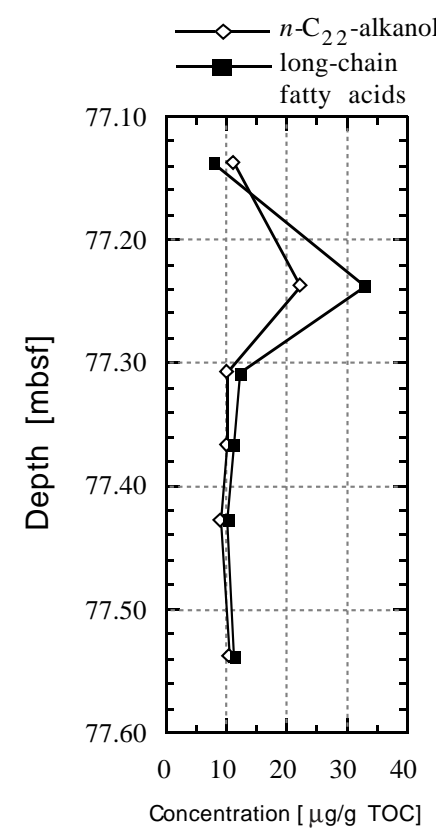

Figure 8. Comparison of downhole trends of organic-carbon-normalized concentrations of $n$-docosan-1-ol and the sum of long-chain $n$-fatty acids $\left(\mathrm{C}_{21}-\mathrm{C}_{30}\right)$ in selected sediments from Section 161-977A-9H-5.

Table 2. Compilation of homologous and isomeric $\boldsymbol{n}$-alkandiols and their main mass spectral characteristics from Hole 977A sediments.

\begin{tabular}{cccc}
\hline & & \multicolumn{2}{c}{ Mass spectral peaks (m/z) } \\
\cline { 3 - 4 } Diol & Scan no. & $\mathbf{M}^{+}$ & \multicolumn{1}{c}{ Diagnostic ions } \\
\hline$n-\mathrm{C}_{26}(1,13)$ & 3979 & $542(-)$ & $527,359(40), \mathbf{2 8 5}, 149$ \\
$n-\mathrm{C}_{26}(1,14)$ & 3979 & $542(-)$ & $527,373(30), \mathbf{2 7 1}, 149$ \\
$n-\mathrm{C}_{28}(1,13)$ & 4217 & $570(-)$ & $555,359(45), \mathbf{3 1 3}, 149$ \\
$n-C_{28}(1,14)$ & 4217 & $570(-)$ & $555,373(40), \mathbf{2 9 9}, 149$ \\
$n-C_{30}(1,15)$ & 4505 & $598(-)$ & $583(1), 387(40), \mathbf{3 1 3}, 149(25)$ \\
$n-\mathrm{C}_{32}(1,15)$ & 4895 & $626(-)$ & $611(1), 387(40), \mathbf{3 4 1}, 149(35)$
\end{tabular}

Note: Base peak (100\%) in bold; relative intensity of selected ions in parentheses in \%; $-=$ not detected

\section{Pentacyclic Triterpenoid Ketones}

The concentrations of two angiosperm pentacyclic triterpenoid ketones, lup-20(29)-en-3-one and olean-12-en-3-one, closely correlate with each other $(R=0.98)$. In contrast to this, the concentration of friedelan-3-one has a different depth profile, with a decrease toward the top of the studied section. This is taken as evidence of different taxonomic sources of friedelan-3-one and the other two triterpenoid ketones. As a terrestrial biomarker friedelan-3-one, other than lup-20(29)-en-3-one and olean-12-en-3-one, is mostly associated with monocotyledons (Das and Mahato, 1983). Monocotyledons in general prefer open, thinly vegetated areas and are more robust under rough climatic conditions. The decreasing upward trend of friedelan3 -one concentration may indicate a climatic change to higher temperatures and increasingly dense wood vegetation on land during the deposition of the sediment interval studied. This would be consistent with the temperature trend calculated from the alkenone index.

\section{Sterols}

More than 50 different free sterols were detected and quantified (Tables 3, 4). Among them, cholesterol (i), 5 $\alpha$-cholestan-3ß-ol (j), 24methylcholesta-5,22(E)-dien-3ß-ol(A), 24-methyl-5 $\alpha(\mathrm{H})$-cholest-22 


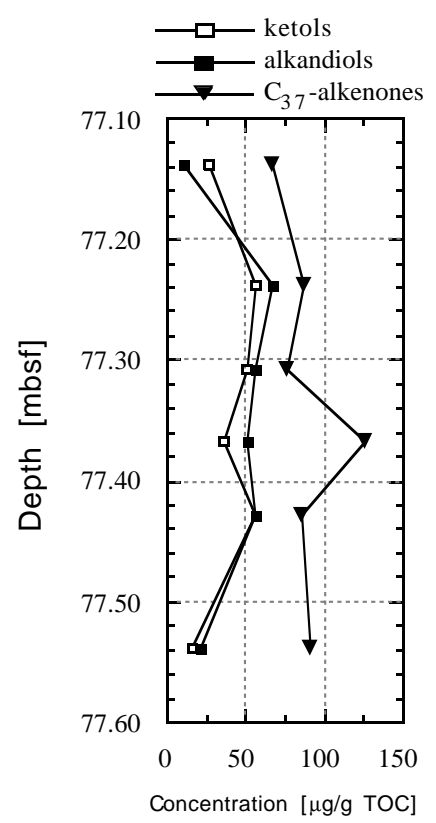

Figure 9. Comparison of downhole trends of organic-carbon normalized concentrations of 1-hydroxy- $n$-alkan- $n$-ones, alkan-1,n-diols, and long-chain $n$ alkenones in selected sediments from Section 161-977A-9H-5.

(E)-en-3ß-ol (B), 24-ethylcholest-5-en-3ß-ol ( $\left.\mathbf{M}^{\prime}\right)$, 23,24-dimethyl$5 \alpha(\mathrm{H})$-cholestan-3ß-ol $\left(\mathrm{N}^{\prime}\right.$; note that $\mathrm{M}^{\prime}$ and $\mathrm{N}^{\prime}$ coelute with fucosterol, $\mathrm{L}^{\prime}$, but the former two compounds represent the main part of the peak), and 24-ethyl-5 $\alpha(\mathrm{H})$-cholestan-3ß-ol $\left(\mathrm{P}^{\prime}\right)$ are the main free sterols in the six samples together with the 4-methylsterols $4 \alpha, 24$-dimethyl-5 $\alpha(\mathrm{H})$-cholestan-33-ol $\left(\mathrm{Q}^{\prime}\right.$; note that $\mathrm{P}^{\prime}$ and $\mathrm{Q}^{\prime}$ coelute with isofucosterol, $\mathrm{R}^{\prime}$, but the former two compounds represent the main part of the peak), dinosterol $\left(\mathrm{C}^{\prime \prime}\right)$, and two isomers of $4 \alpha, 23,24$-trimethyl$5 \alpha(\mathrm{H})$-cholestan-3ß-ol ( $\mathrm{H}^{\prime \prime}$ and $\left.\mathrm{I}^{\prime \prime}\right)$.

Over the depth interval studied, the distribution patterns of the sterols exhibit a large variation (Table 4). The relative proportions of $\mathrm{C}_{28}$ and $\mathrm{C}_{30}$ sterols as a fraction of total sterols correlate with the TOC content, while the summed concentration of the $\mathrm{C}_{29}$ sterols steadily increases with decreasing sediment depth. The $\mathrm{C}_{27}$ sterol concentrations have an inverse relationship to that of the $\mathrm{C}_{29}$ sterols as a function of depth. This indicates an increase of terrestrial influence with time. The triangular Huang-Meinschein diagram of sterol carbon number distributions (Fig. 11) illustrates this trend. This observation is in contrast, however, to the interpretations based on the homologous series of $n$-alkanes, $n$-fatty acids, and $n$-alcohols. They show a higher deposition of marine organic matter in the 63- to 65-cm interval. It is conceivable that the sterol carbon number assignment to marine and terrigenous sources of Huang and Meinschein $(1976,1979)$ does not strictly hold here. Except for 23,24-dimethyl-5 $\alpha(\mathrm{H})$ cholestan-3B-ol ( $\left.\mathrm{N}^{\prime}\right)$, all of the $\mathrm{C}_{28}$ and $\mathrm{C}_{29}$ sterols, which are the main sterols in the Alboran Sea sediments, have been shown to be produced also by marine organisms and to occur in sediments dominated by marine organic matter (Volkman, 1986). In particular, 24-ethyl$5 \alpha(\mathrm{H})$-cholestan-3ß-ol $\left(\mathrm{P}^{\prime}\right)$ may be produced in relatively large amounts by marine phytoplankton. In addition, the Huang-Meinschein diagram does not take into account the occurrence of $\mathrm{C}_{26}$ and $\mathrm{C}_{30}$ sterols, which are all from marine sources (Volkman, 1986). This is particularly true for the main 4-methyl $\mathrm{C}_{30}$ sterols; $4 \alpha, 23,24-$ trimethyl-5 $\alpha(\mathrm{H})$-cholest-22(E)-en-3ß-ol (dinosterol, $\mathrm{C}^{\prime \prime}$ ), and $4 \alpha, 23$, 24-trimethyl-5 $\alpha(\mathrm{H})$-cholestan-3B-ol ( $\mathrm{H}^{\prime \prime}$ and $\left.\mathrm{I}^{\prime \prime}\right)$ are produced by dinoflagellates (Alam et al., 1979; Kokke et al., 1981). Dinoflagellates are also regarded as the main source of the other 4-methylsterols (de Leeuw et al., 1983). Based on this rationalization, the sterols in the

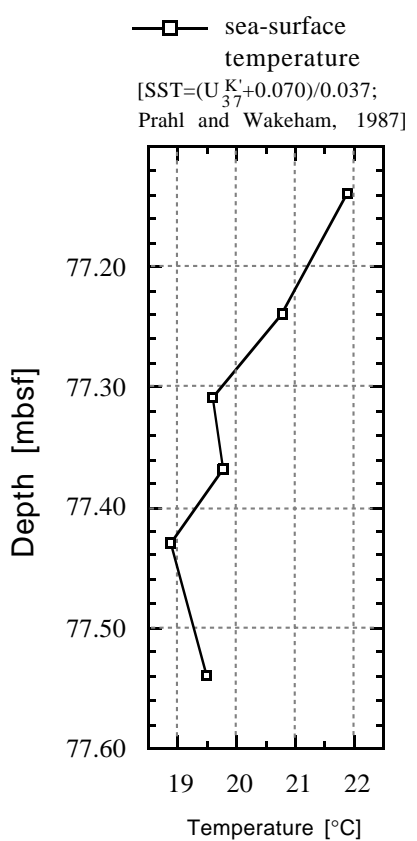

Figure 10. Reconstructed sea-surface paleotemperatures in the 77.1-77.6 mbsf depth interval in Hole 977A.

Hole 977A sediments show an increasing marine bioproductivity during deposition of the organic-matter-rich layer, in addition to an obvious higher terrigenous inflow, as revealed by the $n$-alkane concentration profile.

\section{Lignin Phenols}

Lignin is only produced by land plants except eulithoral grasses (Leo and Barghoorn, 1970; Quackenbush et al., 1986). Lignin may comprise $35 \%$ to $40 \%$ of the dry mass of wood (e.g., Beyer and Walter, 1981) and over $50 \%$ of the global primary production can be assigned to vascular plants (Olson et al., 1985; Martin et al., 1987). Moreover, only some fungi are able to degrade lignin, which renders it very stable over long periods of time (Hedges et al., 1988; Goñi et al., 1993). These three parameters, mass, ubiquity, and persistence, make lignin a suitable tracer for organic material of terrigenous origin.

The summed concentrations of the lignin phenols are usually termed $\lambda$ or $\Lambda$, where $\lambda$ is defined as the sum of the vanillyl and syringyl phenols in $\mathrm{mg} / 100 \mathrm{~g}$ TOC (Hedges and Parker, 1976), while $\Lambda$ includes the cinnamyl phenols as well. The p-hydroxyphenols are not considered, because they can also come from marine sources. The lignin phenols show depth profiles similar to those of the straightchain homologous series and the sterols, that is, during the deposition of the organic-matter-rich layer there is a slightly less allochthonous supply than before and after this time (Fig. 12). It has to be noted, however, that the concentrations of lignin phenols measured in the Alboran Basin sediments are three orders of magnitude smaller than those reported for Holocene sediments by Hedges and Parker (1976) and Goñi and Hedges (1990); therefore, concentrations of $\lambda$ and $\Lambda$ are in $\mu \mathrm{g} / \mathrm{g}$ TOC here.

\section{CONCLUSIONS}

Two sediment sequences across organic-matter-rich layers from ODP Sites 161-977 in the Alboran Basin (Western Mediterranean Sea), comprising about $3000 \mathrm{yr}$ of sedimentation according to bulk- 
Table 3. Nomenclature of quantitated sterols.

\begin{tabular}{|c|c|}
\hline Symbol & Sterol (in order of elution from GC column) \\
\hline $\mathrm{b}^{\prime}$ & 25-nor-5 $\alpha$-cholest-22(E)-en-3ß-ol \\
\hline $\mathrm{a}$ & $\mathrm{C}_{27}$ ster-22-enol \\
\hline $\mathrm{a}^{\prime}$ & 25 -nor-5 $\alpha$-cholestan-3ß-ol \\
\hline b & 5B-cholestan-3ß-ol \\
\hline $\mathrm{c}$ & 27-nor-24-methyl-5ß-cholestan-3ß-ol \\
\hline d & $5 \beta$-cholestan- $3 \alpha$-ol \\
\hline $\mathrm{e}$ & 27-nor-24-methylcholesta-5,22(E)-dien-3ß-ol \\
\hline $\mathrm{f}$ & 27-nor-24-methyl-5 $\alpha$-cholest-22(E)-en-3ß-ol \\
\hline $\mathrm{g}$ & cholesta-5,22(E)-dien-3ß-ol \\
\hline $\mathrm{h}$ & $5 \alpha$-cholest-22(E)-en-3ß-ol \\
\hline $\mathrm{i}$ & cholest-5-en-3ß-ol \\
\hline $\mathrm{j}$ & $5 \alpha$-cholestan-3ß-ol \\
\hline $\mathrm{k}$ & 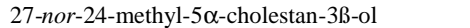 \\
\hline A & 24-methylcholesta-5,22(E)-dien-3ß-ol \\
\hline B & 24-methyl-5 $\alpha$-cholest-22(E)-en-3ß-ol \\
\hline 1 & $5 \alpha$-cholest-7-en-3ß-ol \\
\hline $\mathrm{C}$ & $\mathrm{C}_{28}$ stanol \\
\hline$A^{\prime}$ & $4 \alpha, 24$-dimethylcholest-N-en-3ß-ol \\
\hline $\mathrm{D}$ & 24-methylcholesta-5,24(28)-dien-3ß-ol \\
\hline $\mathrm{E}$ & $4 \alpha$-methyl-5 $\alpha$-cholestan- $3 \beta$-ol \\
\hline $\mathrm{B}^{\prime}$ & $4 \alpha, 24$-dimethyl-5ß-cholest-22(E)-en-3ß-ol \\
\hline $\mathrm{F}$ & 24-methylcholest-5-en-3B-ol \\
\hline G & 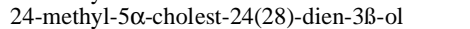 \\
\hline $\mathrm{H}$ & 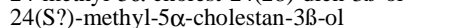 \\
\hline I & $24(\mathrm{R}$ ?)-methyl-5 $\alpha$-cholestan-3ß-ol \\
\hline $\mathrm{C}^{\prime}$ & $4 \alpha, 24$-dimethyl-5 $\alpha$-cholest-22(E?)-en-3ß-ol \\
\hline $\mathrm{D}^{\prime}$ & 23,24-dimethylcholesta-5,22(E)-dien-3ß-ol \\
\hline$A^{\prime \prime}$ & $4 \alpha, 23,24$-trimethyl-cholesta-N,22-dien-3ß-ol \\
\hline $\mathrm{J}$ & $\mathrm{C}_{28}$ stanol \\
\hline $\mathrm{K}$ & $\mathrm{C}_{28}$ steradienol \\
\hline $\mathrm{E}^{\prime}$ & 23,24 -dimethyl-5 $\alpha$-cholest- 22 (E)-en- $3 \beta$-ol \\
\hline $\mathrm{F}^{\prime}$ & 24-ethylcholesta-5,22(E)-dien-3ß-ol \\
\hline $\mathrm{G}^{\prime}$ & 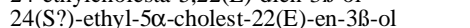 \\
\hline $\mathrm{H}^{\prime}$ & $4 \alpha, 24$-dimethyl-5 $\alpha$-cholest-22(Z?)-en-3ß-ol \\
\hline $\mathrm{I}^{\prime}$ & 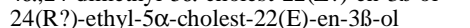 \\
\hline $\mathrm{B}^{\prime \prime}$ & $\mathrm{C}_{30}$ stenol \\
\hline $\mathrm{J}^{\prime}$ & $\mathrm{C}_{29}$ stenol \\
\hline $\mathrm{K}^{\prime}$ & 23,24-dimethylcholest-5-en-3ß-ol \\
\hline $\mathrm{L}^{\prime}$ & 24-ethylcholesta-5,24(28E)-dien-3ß-ol \\
\hline $\mathrm{M}^{\prime}$ & 24-ethylcholest-5-en-3ß-ol \\
\hline $\mathrm{N}^{\prime}$ & 23,24-dimethyl-5 $\alpha$-cholestan- $3 \beta$-ol \\
\hline $\mathrm{O}^{\prime}$ & $\mathrm{C}_{29}$ stanol \\
\hline $\mathrm{P}^{\prime}$ & 24 -ethyl-5 $\alpha$-cholestan- $3 \beta$-ol \\
\hline$Q^{\prime}$ & 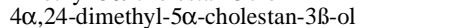 \\
\hline $\mathrm{R}^{\prime}$ & 24-ethylcholesta-5,24(28Z)-dien-3ß-ol \\
\hline $\mathrm{C}^{\prime \prime}$ & $4 \alpha, 23,24$-trimethyl-5 $\alpha$-cholestan $-3 \beta$-ol \\
\hline $\mathrm{D}^{\prime \prime}$ & $4 \alpha$-methyl-24-ethyl- $5 \alpha$-cholest-22(E)-en-3ß-ol \\
\hline$S^{\prime}$ & $\mathrm{C}_{29}$ ster-24(28)-enol \\
\hline $\mathrm{T}^{\prime}$ & 24 -ethyl-5 $\alpha$-cholest-7-en-3ß-ol \\
\hline $\mathrm{E}^{\prime \prime}$ & 24-propylcholesta-5,24(28Z)-dien-3ß-ol \\
\hline $\mathrm{F}^{\prime \prime}$ & $4 \alpha, 23,24$-trimethyl-5 $\alpha$-cholest- 7 -en $-3 \beta$-ol \\
\hline $\mathrm{G}^{\prime \prime}$ & $4 \alpha, 23,24$-trimethylcholest-N-en $-3 \beta$-ol \\
\hline $\mathrm{H}^{\prime \prime}$ & $4 \alpha, 23,24$ (S?)-trimethyl-5 $\alpha$-cholestan -3ß-ol \\
\hline $\mathrm{I}^{\prime \prime}$ & 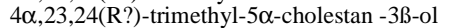 \\
\hline
\end{tabular}

sedimentation rates (Comas, Zahn, Klaus, et al., 1996), were investigated for bulk organic carbon and carbonate content; molecular analyses on the extractable bitumens were performed on the sequence in which a maximum organic carbon content of $2.27 \%$ had been determined. The TOC profiles clearly indicate a strong variation of depositional conditions with respect to organic matter supply and preservation, but this effect is not as pronounced as during times of sapropel formation in the Eastern Mediterranean Sea. Over the interval studied, alkenone-derived sea-surface temperatures increased by about $3^{\circ} \mathrm{C}$. The molecular composition of GC-amenable biomarkers in the organic-matter-rich layer is broadly similar to the biomarker distributions in the underlying and overlying sediments. An elevated marine-organic-matter supply in the organic-matter-rich layer is indicated by an increase in the concentrations of sterols, long-chain diols, and keto-ols. Because concentrations of terrigenous long-chain $n$-alkanes and $n$-alcohols also rise in this layer, an increased terrigenous run-off may have fertilized marine bioproductivity. A change of continental climate to higher humidity may have been the driving force for this.

\section{ACKNOWLEDGMENTS}

We are indebted to Prof. P.A. Meyers (University of Michigan, Ann Arbor) for selecting samples on board the JOIDES Resolution during Leg 161. We thank J. Lobbes (Alfred Wegener Institute for Polar and Marine Research, Bremerhaven) for advice and technical support in the analysis of lignin phenols. We appreciate the reviews and helpful comments of Dr. Eric Lichtfouse (Laboratoire Sols et Environnement, INRA-ENSAIA/INPL, Vandoeuvre-les-Nancy) and Dr. Torren M. Peakman (University of Bristol).

\section{REFERENCES}

Abrantes, F., 1988. Diatom productivity peak and increased circulation during the latest Quaternary: Alboran Basin (western Mediterranean). Mar. Micropaleontol., 13:79-96.

Alam, M., Samsing, T.B., Busky, E.L., Martinez, D.R., and Ray, S.M., 1979. Dinoflagellate sterols I: sterols of dinoflagellates of Gonyaulax sp. Steroids, 33:197-203.

Arnone, R.A., Wiesenburg, D.A., and Saunders, K., 1990. The origin and characteristics of the Algerian current. J. Geophys. Res., 95:1587-1598.

Beyer, H., and Walter, W., 1981. Lehrbuch der organischen Chemie (19th ed.): Stuttgart (Hirzel).

Blumer, M., Guillard, R.R.L., and Chase, T., 1971. Hydrocarbons of marine phytoplankton. Mar. Biol., 8:183-189.

Cardoso, J., Brooks, P.W., Eglinton, G., Goodfellow, R., Maxwell, J.R., and Philip, R.P., 1976. Lipids of recently deposited algal mats at Laguna Mormona, Baja California. In Nriagu, J.O. (Ed.), Environmental Biogeochemistry, 149-174.

COHMAP Members, 1988. Climatic changes of the last 18,000 years: observations and model simulations. Science, 241:1043-1052.

Comas, M.C., Zahn, R., Klaus, A., et al., 1996. Proc. ODP, Init. Repts., 161: College Station, TX (Ocean Drilling Program).

Das, M.C., and Mahato, S.B., 1983. Triterpenoids. Phytochem., 22:10711095.

de Leeuw, J.W., Rijpstra, W.I.C., and Schenck, P.A., 1981. The occurrence and identification of $\mathrm{C}_{30}, \mathrm{C}_{31}$, and $\mathrm{C}_{32}$ alkan-1,15-diols and alkan-15-one1-ols in Unit I and Unit II Black Sea sediments. Geochim. Cosmochim. Acta, 45:2281-2285.

de Leeuw, J.W., Rijpstra, W.I.C., Schenck, P.A., and Volkman, J.K., 1983. Free, esterified, and residual bound sterols in Black Sea Unit I sediments. Geochim. Cosmochim. Acta, 47:455-465.

Eggers, J., 1994. Charakterisierung des Eintrages von organischen Substanzen anhand von Markerverbindungen in marinen Ökosystemen. Diplomarbeit, Univ. of Bremen.

Eglinton, G., Hamilton, R.J., Raphael, R.A., and Gonzalez, A.G., 1962. Hydrocarbon constituents of the wax coatings of plant leaves: a taxonomic survey. Nature, 193:739-742.

Emeis, K.-C., Robertson, A.H.F., Richter, C., et al., 1996. Proc. ODP, Init. Repts., 160: College Station, TX (Ocean Drilling Program).

EUROMODEL Group, 1995. Progress from 1989 to 1992 in understanding the circulation of the Western Mediterranean Sea. Oceanol. Acta, 18:255-271.

Giger, W., and Schaffner, C., 1977. Aliphatic, olefinic and aromatic hydrocarbons in recent sediments of a highly eutrophic lake. In Campos, R., and Goñi, J. (Eds.), Adv. Org. Geochem., 1977, 375-390.

Goñi, M.A., and Hedges, J.I., 1990. The diagenetic behavior of cutin acids in buried conifer needles and sediments from coastal marine environment. Geochim. Cosmochim. Acta, 54:3083-3093.

Goñi, M.A., Nelson, B., Blanchette, R.A., and Hedges, J.I., 1993. Fungal degradation of wood lignins: geochemical perspectives from $\mathrm{CuO}-$ derived phenolic dimers and monomers. Geochim. Cosmochim. Acta, 57:3985-4002.

Grousset, F.E., Joron, J.L., Biscaye, P.E., Latouche, C., Treuil, M., Maillet, N., Faugeres, J.C., and Gonthier, E., 1988. Mediterranean outflow through the Strait of Gibraltar since 18,000 years B.P.: mineralogical and geochemical arguments. Geo-Mar. Lett., 8:25-34. 
Harrington, G.W., Beach, D.H., Dunham, J.E., and Holz, G.G., 1970. The polyunsaturated fatty acids of marine dinoflagellates. J. Protozool., 17:213-219.

Hedges, J.I., Blanchette, R.A., Weliky, K., and Devol, A.H., 1988. Effects of fungal degradation on the $\mathrm{CuO}$ oxidation products of lignin: a controlled laboratory study. Geochim. Cosmochim. Acta, 52:2717-2726.

Hedges, J.I., and Parker, P.L., 1976. Land derived organic matter in surface sediments from the Gulf of Mexico. Geochim. Cosmochim. Acta, 40:1019-1029.

Hinrichs, K.-U., Rullkötter, J., and Stein, R., 1995. Preliminary assessment of organic geochemical signals in sediments from Hole 893A, Santa Barbara Basin, offshore California. In Kennett, J.P., Baldauf, J.G., and Lyle, M. (Eds.), Proc. ODP, Sci. Results, 146 (Pt. 2): College Station, TX (Ocean Drilling Program), 201-211.

Hsü, K.J., Montadert, L., et al., 1978. Init. Repts. DSDP, 42 (Pt. 1): Washington (U.S. Govt. Printing Office).

Huang, W.Y., and Meinschein, W.G., 1976. Sterols as source indicators of organic materials in sediments. Geochim. Cosmochim. Acta, 40:323-330. , 1979. Sterols as ecological indicators. Geochim. Cosmochim. Acta, 43:739-745.

Kastens, K.A., Mascle, J., et al., 1990. Proc. ODP, Sci. Results, 107: College Station, TX (Ocean Drilling Program).

Kenyon, C.N., Rippka, R., and Stanier, R.Y., 1972. Fatty acid composition and physiological properties of some filamentous blue-green algae. Archives Microbiol., 83:216-236.

Kidd, R.B., Cita, M.B., and Ryan, W.B.F., 1978. Stratigraphy of eastern Mediterranean sapropel sequences recovered during DSDP Leg 42A and their paleoenvironmental significance. In Hsü, K.J., Montadert, L., et al., Init. Repts. DSDP, 42 (Pt. 1): Washington (U.S. Govt. Printing Office), 421-443.

Kinder, T.H., and Parrilla, G., 1987. Yes, some of the Mediterranean outflow does come from great depth. J. Geophys. Res., 91:2901-2906.

Kokke, W.C.M.C., Fenical, W., and Djerassi, C., 1981. Sterols with unusual nuclear unsaturation from three cultured marine dinoflagellates. Phytochemistry, 20:127-134.

Leo, R.F., and Barghoorn, E.S., 1970. Phenolic aldehydes: generation from fossil woods and carbonaceous sediments by oxidative degradation. Science, 168:582-584.

Martin, J.H., Knauer, G.A., Karl, D.M., and Broenkow, W.W., 1987. VETEX: carbon cycling in the northeast Pacific. Deep-Sea Res., 34:267285 .

McCarthy, R.D., and Duthie, A.H., 1962. A rapid method for separation of free fatty acids from other lipids. J. Lipid Res., 3:117-119.

McIver, R.D., 1975. Hydrocarbon occurrences from JOIDES Deep Sea Drilling Project. Proc. Ninth Petrol. Congr., 269-280.

Minas, H.J., Coste, B., and Minas, M., 1984. Océanographie du détroit de Gibraltar et des parages annexes. Cour. CNRS, 57:10-17.

Morris, R.J., and Brassell, S.C., 1988. Long-chain alkanediols: biological markers of cyanobacteria in sediments. Lipids, 23:256-258.

Olson, J.S., Garrels, R.M., Berner, R.A., Armentano, T.V., Dyer, M.I., and Talalon, D.H., 1985. The natural carbon cycle. In Trabalka, J.R. (Ed.), Atmospheric Carbon Dioxide and the Global Carbon Cycle. US Dept. Energy, 175-213.

Patterson, G.W., 1970. Effect of culture temperature on fatty acid compositions of Chlorell sorokiniana. Lipids, 5:547-600.

Prahl, F.G., and Wakeham, S.G., 1987. Calibration of unsaturation patterns in long-chain ketone compositions for paleotemperature assessment. Nature, 330:367-369.

Prieur, L., Copin-Montegut, C., and Claustre, H., 1993. Biophysical aspects of "Almofront-1," an intensive study of a geostrophic frontal jet. Ann. Inst. Oceanogr., 69:71-86.
Quackenbush, R.C., Bunn, D., and Richards, F.A., 1986. HPLC determination of phenolic acids in the water-soluble extract of Zostera marina L., Eelgrass. Aquat. Bot., 24:83-89.

Radke, M., Willsch, H., and Welte, D.H., 1980. Preparative hydrocarbon group type determination by automated medium pressure liquid chromatography. Anal. Chem., 52:406-411.

Ryan, W.B.F., Hsü, K.J., et al., 1973. Init. Repts. DSDP, 13 (Pts. 1 and 2): Washington (U.S. Govt. Printing Office).

Still, W.C., Kahn, M., and Mitra, A., 1978. Rapid chromatographic technique for preparative separations with moderate resolutions. J. Org. Chem., 43:2923-2926.

Summerhayes, C.P., 1981. Organic facies of Mid-Cretaceous black shales in the deep north Atlantic. AAPG Bull., 65:3264-2380.

Tintoré, J., La Violette, P.E., Blade, I., and Cruzado, A., 1988. A study of an intense density front in the eastern Alboran Sea: the Almeria-Oran front. J. Phys. Oceanogr., 18:1384-1397.

Tintoré, J., Viúdez, A., Gomis, D., Alonso, S., and Werner, F.E., 1995. Mesoscale variability and Q vector vertical motion in the Alboran Sea. In La Violette, P.E. (Ed.), Seasonal and Interannual Variability of the Western Mediterranean Sea: Washington (Am. Geophys. Union), Coastal and Estuarine Studies, 46:47-71.

Tissot, B., Demaison, G., Masson, P., Delteil, J.R., and Combaz, A., 1980. Paleoenvironment and petroleum potential of mid-Cretaceous black shales in the Atlantic Basins. AAPG Bull., 64:2051-2063.

Tomadin, L., Lenaz, R., Landuzzi, V., Mazzucottelli, A., and Vannucci, R., 1984. On wind-blown dusts over the central Mediterranean. Oceanol. Acta, 7:13-24.

Vergnaud-Grazzini, C., and Pierre, C., 1991. High fertility in the Alboran Sea since the Last Glacial Maximum. Paleoceanography, 6:519-536.

Volkman, J.K., 1986. A review of sterol markers for marine and terrigenous organic matter. Org. Geochem., 9:83-99.

Volkman, J.K., Barrett, S.M., Dunstan, G.A., and Jeffrey, S.W., 1992. C ${ }_{30 \_} C_{32}$ alkyl diols and unsaturated alcohols in microalgae of the class Eustigmatophyceae. Org. Geochem., 18:131-138.

Volkman, J.K., Eglinton, G., and Corner, E.D.S., 1980a. Sterols and fatty acids of marine diatom Biddulphia sinensis. Phytochemistry, 19:18091813 .

Volkman, J.K., Eglinton, G., Corner, E.D.S., and Forsberg, T.E.V., 1980 b. Long-chain alkenes and alkenones in the marine coccolithophorid Emiliania huxleyi. Phytochemistry, 19:2619-2622.

Volkman, J.K., Eglinton, G., Corner, E.D.S., and Sargent, J.R., 1980c. Novel unsaturated straight-chain $\mathrm{C}_{37-} \mathrm{C}_{39}$ methyl and ethyl ketones in marine sediments and a coccolithophore Emiliania huxleyi. In Douglas, A.G., and Maxwell, J.R. (Eds.), Advances in Organic Geochemistry 1979: Oxford (Pergamon Press), 219-228.

Volkman, J.K., Smith, D.J., Eglinton, G., Forsberg, T.E.V., and Corner, E.D.S., 1981. Sterol and fatty acid composition of four marine Haptophycean algae. J. Mar. Biol. Assoc., 61:509-527.

Zahn, R., Sarnthein, M., and Erlenkeuser, H., 1987. Benthic isotope evidence for changes of the Mediterranean outflow during the late Quaternary. Paleoceanography, 2:543-559.

Date of initial receipt: 21 May 1997

Date of acceptance: 22 September 1997

Ms 161SR-273 
Table 4. Sterol concentrations in sediments from Section 161-977A-9H-4, intervals $63-65 \mathrm{~cm}, 73-75 \mathrm{~cm}, 80-82 \mathrm{~cm}, 86-88 \mathrm{~cm}, 92-94 \mathrm{~cm}$, and $103-105 \mathrm{~cm}$.

\begin{tabular}{|c|c|c|c|c|c|c|c|c|c|c|c|c|c|}
\hline \multirow[b]{3}{*}{ Symbol } & \multirow[b]{3}{*}{$\begin{array}{l}\text { No. of C } \\
\text { atoms }\end{array}$} & \multicolumn{12}{|c|}{$161-977-9 \mathrm{H}-5$} \\
\hline & & \multicolumn{2}{|c|}{$63-65 \mathrm{~cm}$} & \multicolumn{2}{|c|}{$73-75 \mathrm{~cm}$} & \multicolumn{2}{|c|}{$80-82 \mathrm{~cm}$} & \multicolumn{2}{|c|}{$86-88 \mathrm{~cm}$} & \multicolumn{2}{|c|}{$92-94 \mathrm{~cm}$} & \multicolumn{2}{|c|}{$103-105 \mathrm{~cm}$} \\
\hline & & $\begin{array}{c}\mathrm{ng} / \mathrm{g} \\
\text { sediment }\end{array}$ & $\begin{array}{l}\mu \mathrm{g} / \mathrm{g} \\
\text { TOC }\end{array}$ & $\begin{array}{c}\mathrm{ng} / \mathrm{g} \\
\text { sediment }\end{array}$ & $\begin{array}{l}\mu \mathrm{g} / \mathrm{g} \\
\mathrm{TOC}\end{array}$ & $\begin{array}{c}\mathrm{ng} / \mathrm{g} \\
\text { sediment }\end{array}$ & $\begin{array}{l}\mu \mathrm{g} / \mathrm{g} \\
\mathrm{TOC}\end{array}$ & $\begin{array}{c}\mathrm{ng} / \mathrm{g} \\
\text { sediment }\end{array}$ & $\begin{array}{l}\mu \mathrm{g} / \mathrm{g} \\
\text { TOC }\end{array}$ & $\begin{array}{c}\mathrm{ng} / \mathrm{g} \\
\text { sediment }\end{array}$ & $\begin{array}{l}\mu \mathrm{g} / \mathrm{g} \\
\text { TOC }\end{array}$ & $\begin{array}{c}\mathrm{ng} / \mathrm{g} \\
\text { sediment }\end{array}$ & $\begin{array}{l}\mu \mathrm{g} / \mathrm{g} \\
\mathrm{TOC}\end{array}$ \\
\hline $\mathrm{b}^{\prime}$ & 26 & 3.5 & 0.4 & 34.5 & 1.8 & 10.5 & 0.5 & 20.1 & 1.0 & 28.8 & 2.0 & 3.6 & 0.4 \\
\hline $\mathrm{a}$ & 27 & n.d. & n.d. & 17.9 & 0.9 & n.d. & n.d. & n.d. & n.d. & n.d. & n.d. & n.d. & n.d. \\
\hline$a^{\prime}$ & 26 & n.d. & n.d. & n.d. & n.d. & 3.7 & 0.2 & 26.0 & 1.3 & 4.2 & 0.3 & n.d. & n.d. \\
\hline $\mathrm{b}$ & 27 & 1.9 & 0.2 & 21.1 & 1.1 & 12.2 & 0.5 & 28.8 & 1.5 & 10.6 & 0.7 & 3.3 & 0.4 \\
\hline $\mathrm{c}$ & 27 & 6.5 & 0.7 & 6.5 & 0.3 & n.d. & n.d. & n.d. & n.d. & 12.2 & 0.8 & n.d. & n.d. \\
\hline d & 27 & 2.8 & 0.3 & 60.9 & 3.1 & 13.6 & 0.6 & 20.1 & 1.0 & 58.0 & 4.0 & 4.0 & 0.4 \\
\hline e & 27 & 4.8 & 0.5 & 20.3 & 1.0 & 9.1 & 0.4 & n.d. & n.d. & 22.2 & 1.5 & n.d. & n.d. \\
\hline f & 27 & n.d. & n.d. & 57.5 & 3.0 & 13.5 & 0.6 & 97.0 & 5.0 & 38.7 & 2.7 & 5.7 & 0.6 \\
\hline $\mathrm{g}$ & 27 & 4.7 & 0.5 & 37.8 & 2.0 & 37.6 & 1.7 & 46.0 & 2.4 & 59.8 & 4.1 & 8.0 & 0.9 \\
\hline $\mathrm{h}$ & $* * 27$ & 8.2 & 0.9 & 94.0 & 4.8 & 48.8 & 2.2 & 41.3 & 2.1 & 82.1 & 5.7 & 32.2 & 3.6 \\
\hline $\mathrm{i}$ & $* * 27$ & 138.3 & 15.7 & 232.4 & 12.0 & 236.9 & 10.4 & 451.6 & 23.3 & 273.4 & 18.9 & 326.2 & 36.2 \\
\hline j & $* * 27$ & 40.0 & 4.5 & 262.0 & 13.5 & 117.6 & 5.2 & 115.8 & 6.0 & 195.3 & 13.5 & 67.5 & 7.5 \\
\hline A & $* * 28$ & 10.9 & 1.2 & 148.1 & 7.6 & 150.6 & 6.6 & 123.2 & 6.3 & 188.8 & 13.0 & 30.9 & 3.4 \\
\hline B & $* * 28$ & 16.4 & 1.9 & 238.4 & 12.3 & 88.5 & 3.9 & 106.5 & 5.5 & 191.8 & 13.2 & 32.2 & 3.6 \\
\hline 1 & 27 & 5.6 & 0.6 & 35.5 & 1.8 & 13.4 & 0.6 & 22.2 & 1.1 & 29.0 & 2.0 & 6.5 & 0.7 \\
\hline$C+A^{\prime}+D+E+B^{\prime}$ & $* 28$ & 26.4 & 3.0 & 169.2 & 8.7 & 125.7 & 5.5 & 133.4 & 6.9 & 107.4 & 7.4 & 32.2 & 3.6 \\
\hline $\mathrm{F}+\mathrm{G}+\mathrm{H}$ & 28 & 11.1 & 1.3 & 141.0 & 7.3 & 136.8 & 6.0 & 75.6 & 3.9 & 122.7 & 8.5 & 33.6 & 3.7 \\
\hline$+\mathrm{C}^{\prime}+\mathrm{D}^{\prime}+\mathrm{A}^{\prime \prime} \mathrm{I}$ & $* 29$ & 6.9 & 0.8 & 123.6 & 6.4 & 58.3 & 2.6 & 60.1 & 3.1 & 82.8 & 5.7 & 14.5 & 1.6 \\
\hline $\mathrm{J}$ & 28 & 2.2 & 0.3 & 25.3 & 1.3 & 19.9 & 0.9 & 28.7 & 1.5 & 36.5 & 2.5 & 13.7 & 1.5 \\
\hline $\mathrm{K}+\mathrm{E}^{\prime}+\mathrm{F}^{\prime}+\mathrm{G}^{\prime}$ & $* 29$ & 75.2 & 8.5 & 194.9 & 10.0 & 140.9 & 6.2 & 121.4 & 6.3 & 214.9 & 14.8 & 43.7 & 4.9 \\
\hline $\mathrm{H}^{\prime}+\mathrm{I}^{\prime}$ & 29 & 13.4 & 1.5 & 157.7 & 8.1 & 98.7 & 4.3 & 114.9 & 5.9 & 115.6 & 8.0 & 35.1 & 3.9 \\
\hline $\mathrm{B}^{\prime \prime}$ & 30 & n.d. & n.d. & 14.4 & 0.7 & 6.8 & 0.3 & 13.3 & 0.5 & n.d. & n.d. & n.d. & n.d. \\
\hline $\mathrm{J}^{\prime}$ & 29 & 4.6 & 0.5 & 27.3 & 1.4 & 39.8 & 1.8 & 38.2 & 2.0 & 3.9 & 0.3 & 23.0 & 2.6 \\
\hline $\mathrm{K}^{\prime}$ & 29 & 4.6 & 0.5 & 25.6 & 1.3 & 48.4 & 2.1 & 33.6 & 1.7 & 25.8 & 1.8 & 21.8 & 2.4 \\
\hline $\mathrm{L}^{\prime}+\mathrm{M}^{\prime}+\mathrm{N}^{\prime}$ & 29 & 725.3 & 82.4 & 561.1 & 28.9 & 282.8 & 12.5 & 188.7 & 9.7 & 846.7 & 58.4 & 61.5 & 6.8 \\
\hline $\mathrm{O}^{\prime}$ & 29 & 24.2 & 2.8 & 75.1 & 3.9 & 91.2 & 4.0 & 77.8 & 4.0 & 64.5 & 4.4 & 12.7 & 1.4 \\
\hline $\mathrm{P}^{\prime}+\mathrm{Q}^{\prime}+\mathrm{R}^{\prime}$ & 29 & 169.9 & 19.3 & 459.6 & 23.7 & 250.2 & 11.0 & 244.3 & 12.6 & 405.5 & 28.0 & 76.7 & 8.5 \\
\hline$C^{\prime \prime}$ & $* * 30$ & 100.1 & 11.4 & 387.8 & 20.0 & 333.1 & 14.7 & 476.8 & 24.6 & 315.8 & 21.8 & 99.7 & 11.1 \\
\hline $\mathrm{D}^{\prime \prime}$ & 30 & 7.7 & 0.9 & 37.2 & 1.9 & 36.1 & 1.6 & 40.6 & 2.1 & 25.2 & 1.7 & 7.8 & 0.9 \\
\hline$S^{\prime}$ & 29 & n.d. & n.d. & 30.8 & 1.6 & 45.1 & 2.0 & 17.4 & 0.9 & 8.4 & 0.6 & n.d. & n.d. \\
\hline $\mathrm{T}^{\prime}$ & 29 & n.d. & n.d. & 19.0 & 1.0 & 15.7 & 0.7 & 17.9 & 0.9 & 14.0 & 1.0 & n.d. & n.d. \\
\hline $\mathrm{E}^{\prime \prime}$ & 30 & n.d. & n.d. & 20.9 & 1.1 & 17.4 & 0.8 & 23.5 & 1.2 & 14.8 & 1.0 & n.d. & n.d. \\
\hline $\mathrm{F}^{\prime \prime}$ & 30 & 3.3 & 0.4 & 76.7 & 4.0 & 41.7 & 1.8 & 27.2 & 1.4 & 29.5 & 2.0 & 5.7 & 0.6 \\
\hline $\mathrm{G}^{\prime \prime}$ & 30 & n.d. & n.d. & 7.9 & 0.4 & 6.2 & 0.3 & 10.3 & 0.5 & 6.3 & 0.4 & n.d. & n.d. \\
\hline $\mathrm{H}^{\prime \prime}$ & 30 & 27.5 & 3.1 & 89.0 & 4.6 & 60.7 & 2.7 & 84.7 & 4.4 & 51.2 & 3.5 & 26.2 & 2.9 \\
\hline$I^{\prime \prime}$ & 30 & 47.6 & 5.4 & 144.1 & 7.4 & 115.9 & 5.1 & 135.3 & 7.0 & 88.0 & 6.1 & 33.8 & 3.8 \\
\hline$\Sigma$ & & 1494 & 170 & 4055 & 209 & 2728 & 120 & 3062 & 158 & 3774 & 260 & 1062 & 118 \\
\hline
\end{tabular}

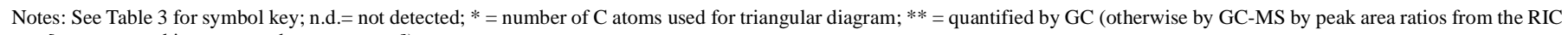
[reconstructed ion current chromatograms]).

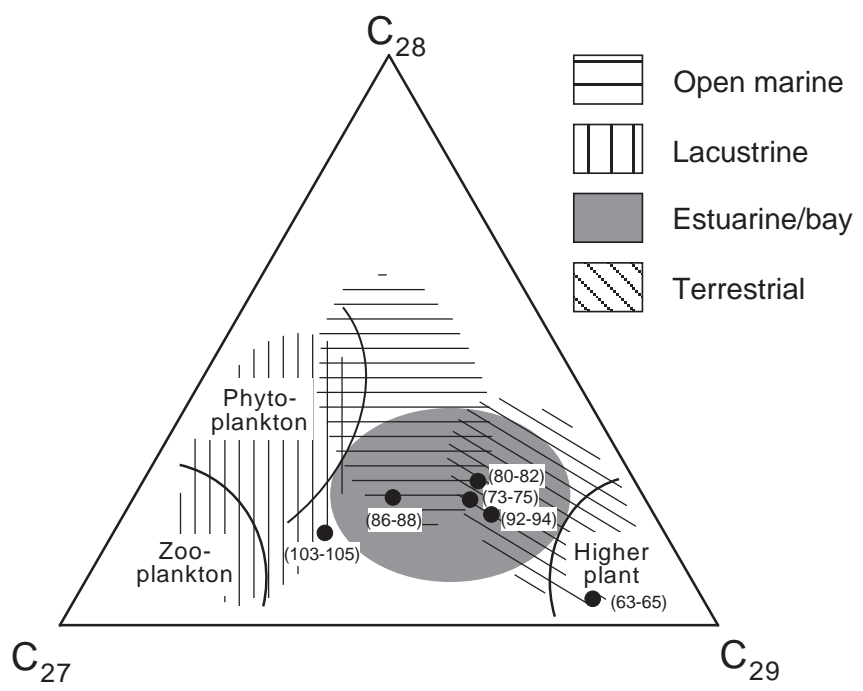

Figure 11. Huang-Meinschein diagram of sterol carbon number distributions for sediments from Section 161-977A-9H-5.

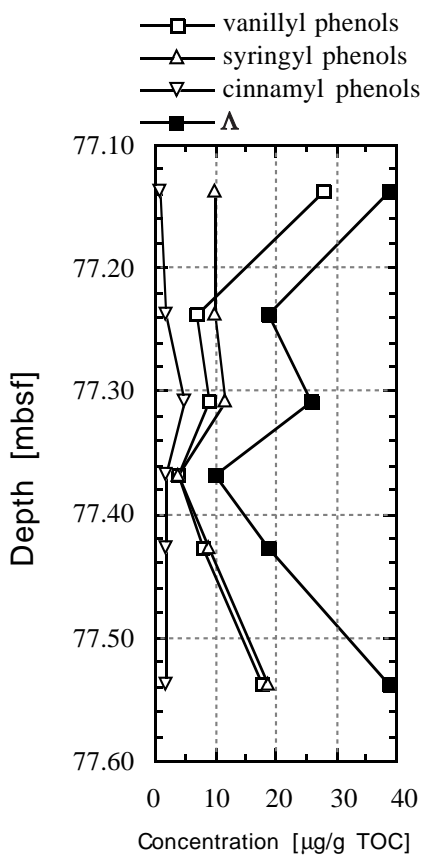

Figure 12. Downhole trends of organic-carbon-normalized concentrations of individual lignin phenols and of their sum $(\Lambda)$ in Section 161-977A-9H-5. 